\title{
Teaching Literature in a Post-Dictatorship Country
}

\author{
Dhurata Lamçja
}

PhD Cand. University of Tirana

\section{Abstract}

Albanian literature curricula in a high school system has incorporated in a few years a lot of concepts, authors and methodology pretending in absorbed and integration of knowledge worldwide on literature teaching process and environment. Analyzing the academic process of constructing the base and the theoretical axis of the teachers, which actually are teaching literature can be noticed easily that a large number of them in their last ten years of their professional carrier has nothing to do with it. Their studies in university stage was only ideologized and focused on socialist realism. The university's curriculum was strictly handicapped and based on the communist ideology on "creating the new people- the communist one", as the literature itself, and every art form was "shaped" as it. Being such a teacher nowadays in Albania you have to face a challenge: You feel prejudged by your "experienced" colleges, who has not accepted and never "known" really the perspective of reading a fiction text as a "open text". You felt yourself "trapped" in textbooks, their sources and their perspective is limited on their authors theoretical backgrounds. Having a parenting and student tradition, mentality as their academic success is based only on "the book" (even if in Albania we have more than 10 years practicing "altertext"-as a possibility of performing the subject program through the book chosen by teachers between three or four possibilities) makes it difficult to provide an "open" experience on learning through a based bibliography. The academic coordinators in pre-university system, aren't always ready for the teacher who want to realize the teaching process leaded by the ideas of globalization, open minded individual, constructive perspective of the personality of the student, on national history and tradition versus "the other".

Keywords: hero-sub/ reality-globalization-individual-perspective-the-other.

\section{Introduction}

Having the possibility of having a full wiew on teaching the literature in high scool meantime gives a lot of challenges faced both from teachers and students. We didn't 
incluse the parents as far as on statistics and on regular studies and analyses made by the coordinating staf, it resuls that a small percentage of the parents have knowledge about the program, about the curricula and about the student's text itself.

Referring to the curricula the concepts of achievement levels are in coherence with the pedagogical principle of competency learning.

Our aim is to analise how the art (literature) text ( a narrative, poetry or drama) fulfill the pedagocical objective and how much are the Albanian student's book in this subject are contemporan. We dare to use such a term- contemporan -as a student's book similar to the student' book of the region, or further.

Our overlook will be concrete on the lessons plans and on the pedagogical review.

\section{Literature review}

Historiographical researches, ideological researches, filosophical and researches based on updated theoretical literature's researches will enlighted the focus.

Concrete literature student's book, in their selected pieces of narratives or poems, the questionnaire and the exercises through them is planned to thrive on a concrete plan of competences and attitudes, through knowledges, new information and their conection on various knowledges fields.

Theoretical concepts dealt with narratives will provide another backround or perspective on social, historical, behavior and philosophical concepts.

\section{Methodology}

Methods of data analysis are not simply neutral techniques because they carry the epistemological, ontological and theoretical assumptions of researchers who developed them (Alvessson and Skoldberg 2000) based on the relational exchange with the assumptions (sometimes different) of the stakeholder who use them.

The presentation of a jurney on Albanian literature history (Hamiti S. 2010) by analyzing in a very different focus is not a simply neutral technique as it carry the epistomological, ontological and theoretical assumption of the literature critique who developed them based on the stakeholder who use them (literature teachers on high schools, students, parents of the students, academic coordinators in high scools, academic staf on educational faculties, students book authors, etc), but a concrete ideolocical, methodogical, sociological, psychological and philosophical strategy on teaching and learning literature in a high school literature class.

The writing procces (artwriting) (bioletra), as creating procces is compounded by:

a-the life writing (jetëshkrimi), (curriculum vitae) as a personal feelings narrative ( Hamiti S. 2010). 
b-handwriting (dorëshkrimi) which is escaped from the generalisations and tend to embrace the personal in which is creating the individual unique of the persona ( the author), (Hamiti S. 2010).

c-scripture (bukurshkrimi) as an escape from the anxious feelings through the art (Hamiti S.2010).

We tend to generalize as the historical view on authors personal and social life, personal backround of knowledges and attitude, personal and unconscious feelings.

Poetic bioletra- their concepts are: uni- the ego (me), the monologue in his universality and imagination, with no time précised but dhe universal time.

Mimetic bioletra- the description and the narrative in writing process is connected to the time and space. The personal and the imaginative gives the opportunity to -the other.

Dramatic bioletra-is the most impersonal and real genre. There is the definition as an imitation of the reality and as a creative illusion of the reality. The drama happens here and now, in the meaning that it relativizing the time and the space as a beyond personal and the dream and the memory as personal categories. The conection with the real the drama is pretending to be adapted to one imitation (mimesis). Aristoteli's catharsis might be interpreted the same as a single unit of sintactic system in a text or as an evocation to the reader to the cleansing of passions (extratextual and it belongs to the spectator or reader).

Formal bioletra (varianta). Literal form is a heritage, a culture, a memory and escaping from it is impossible. The definitions as: dramatic poetry, lyric narrative or symbolic drama are just conventional.

Original bioletra (personalization). The individual creation goes to the originality, means universality undergoing to the unique process of the personalization.

Ideoletra-bioletra (the idea). This is a letrarity totality that doesn't know the boundaries of the tima and space, it can be rapresented with thw figure of an open circle.

\section{Conclusions}

Changing the curricula in terms of changing author is not what are our expextations, diversifying the fragments from the authors is another opportunity of a larger view and a divers class coments and analysis.

Sociological theories might be on the historiographical interpretations, phsycological interpretations mixed up with backround personal datas about the author might be a point in the general discution about the letrarity in a author artwork.

Discusing about the student's book might be overcome as we live in the internet age, but on certain environments such conservative and low income communities we have 
to take in consideration that the student's book is the only confidentional, reliable source and "manual" of their learning. Parent's mentality and mindset about what they believe what a educational system must be is quite clear: they consider the teacher not the person who leads the sudents on the knowledge and the critical thinking but the only authority who knows better about the subject and is the only authority of defining the boundaries of knowledge and attitude. This is a traditional opinion and tend to be a prevailing consideration on teachers and students to. A literature class based only an a student book is not the best .

Teachers theoretical backround is particulary crucial in this process to.

The teachers studies in university was not only ideologized but focused on socialist realism only as the art'method. The university's curriculum was strictly handicapped and based on the communist ideology on "creating the new people- the communist one", as the literature itself, and every art form was "shaped" as it.

Being such a teacher nowadays in Albania you have to face challenges: You feel prejudged by your "experienced" colleges, who has not accepted and never "known" really the perspective of reading a fiction text as a "open text". The diversity of approach on transmiting art values, difersify the method and the pecularity of the act of the communicating in literature class proceed with diverse challenges.

On the historiographical perspective there is an absence of the authors from the region (specifically Balcan's countries). The other, the neighbor is unknown, despite the greek ancient authors.

\section{References}

[1] Barthes R.,[2001], Miti d'ogi, translated by Lonzi L., Torino, Einaudi

[2] Çiraku Y., [1998], Në zbërthim të kodeve letrare, Tiranë,Toena

[3] Dado F. [2003], Poetika, Teoria e veprës letrare, Tiranë, Botimet Toena

[4] Dizionario di Retorica e Stilistica, [2015], Roma, UTET

[5] Eco U., [2007], Gjashtë shëtitje në pyjet e tregimtarisë, translated by Kastrati D., Tiranë, Dituria

[6] Gennette G., [1997], Palinsesti, La letteratura al secondo grado, translated by Novità R., Torino, Einaudi

[7] Hamiti S. \& Shehri Dh. \& Marashi A.\& Petro.R \& Mëniku L., [2011], Gjuha shqipe dhe Letërsia 11, Tiranë, Albas

[8] Hamiti S. \& Shehri Dh. \& Marashi A.\& Petro.R \& Mëniku L., [2011], Gjuha shqipe dhe Letërsia 12, Tiranë, Albas

[9] Hamiti S. \& Shehri Dh. \& Marashi, [2016], Letërsia 10, Tiranë, Albas

[10] Hamiti S. \& Shehri Dh. \& Marashi, [2016], Letërsia 11, Tiranë, Albas

[11] Hamiti S. \& Shehri Dh. \& Marashi, [2016], Letërsia 11, Tiranë, Albas

[12] Hamiti S. \& Shehri Dh. \& Marashi, [2016], Letërsia 12, Tiranë, Albas

[13] Hamiti S. \& Shehri Dh.\& Marashi A. \& Petro.R \& Mëniku L., [2011], Gjuha shqipe dhe Letërsia 10, Tiranë, Albas 
[14] Hamiti S. [2010], Poetika shqiptare, 1-Bioletra, 2-Tematologjia, 3-Albanizma, Tiranë, Shtëpia botuese " 55 "

[15] Hamiti S.[2013], Letërsia moderne shqipe, second edition, Tiranë, UET Press

[16] Jakllari A \& Isufaj V., Letërsia 12 (me zgjedhje), [2018], Tiranë, Albas

[17] Korniza Kurrikulare e Arsimit Parashkollor, [2016], IZHA, Tiranë

[18] Lévi-Straus C., [2009], Antropologia strutturale, translated by Caruso P., Milano, Il Saggiatore

[19] Mëniku L. \& Petro R. \& Jubani A., [2016], Gjuha shqipe 10, Tiranë, Albas

[20] Mëniku L. \& Petro R. \& Jubani A., [2016], Gjuha shqipe 11, Tiranë, Albas

[21] Mëniku L. \& Petro R. \& Jubani A., [2016], Gjuha shqipe 12, Tiranë, Albas

[22] Nivelet e arritjes-Shkalla V dhe VI, [2018], IZHA, Tiranë

[23] Sinani Sh. [2012], Tradita gojore si etnotekst: Studime për etno-folkloristikë krahasimtare. Tiranë: Shtëpia botuese dhe studio letrare "Naimi"

[24] Todorov T., [2007], Letërsia në rrezik, translated by Halimi M., Prishtinë, Buzuku

[25] Udhëzues kurrikular për Gjuhën shqipe, [2018], IZHA, Tiranë

[26] Udhëzues kurrikular për Letërsinë, [2018], IZHA, Tiranë 